\title{
EFFECT OF EMS ON ANTIOXIDANT ENZYME ACTIVITY AND OXIDATIVE STRESS OF TRITICUM AESTIVUM L. VAR HD-2894
}

\author{
SHAILJA DUBEY ${ }^{1}$, RENU BIST ${ }^{1}$, SHRILEKHA MISRA ${ }^{2 *}$ \\ ${ }^{1}$ Department of Bioscience and Biotechnology, Banasthali University, Rajasthan, India, ${ }^{2}$ Department of Hematology, Ohio State University, \\ Columbus, OH, USA \\ Email: shrilekhamisra@gmail.com
}

Received: 23 Oct 2017, Revised and Accepted: 12 Dec 2017

\begin{abstract}
Objective: Ethyl methano sulphonate (Ems), a chemical mutagen is widely used to induce a large number of functional variation in wheat plant. The objective of present study was to determine the activity of enzymatic antioxidants and Lipid peroxidation (LPO) after EMS exposure in a wheat plant in M1, M2 and M3 generation of Triticum aestivum L. var. HD 2894.
\end{abstract}

Methods: Presoaked seeds were treated with EMS for 6 hour with different concentration like 0\%, 0.1\%, 0.2\%, 0.3\%, 0.4\% and 0.5\%. Some biochemical parameter such as Catalase (CAT), ascorbate peroxidase (APX), glutathione reductase (GR) and Lipid peroxidation (LPO) were studied.

Results: Our result showed that EMS affects enzymatic and oxidative parameters in all generation. CAT, GR, APX and LPO activity was found to be reduced in $\mathrm{m} 1$ generation as compared to control. A simultaneous elevation was recorded in the concentration of ems compared to control treated plants after given the exposure of ems in $\mathrm{m} 2$ and $\mathrm{m} 3$ generation. Data analysis of antioxidant and LPO during the $\mathrm{m} 2$ generation showed that the effect of the mutagen on the activity of antioxidant and LPO did not cease in the $\mathrm{m} 1$ but continued to affect the m 2 generation. Analysis of m3 generation showed stability in the activity of antioxidant and LPO from $\mathrm{m} 2$ to $\mathrm{m} 3$ generation.

Conclusion: Lethal dose of ems was determined by the activity of antioxidant under laboratory condition. In this experiment, quantitative determination was applied as a regular procedure. The data analysis showed the activity of antioxidant, LPO and doses of ems concentration in m1, $\mathrm{m} 2$ and $\mathrm{m} 3$ generation. Variability observed on the basis of mean and standard deviation. On the whole, differences between concentrations and treatment time of Ems significantly affect the activity of antioxidant and LPO in all generation.

Keywords: Wheat, Ems, LPO, CAT, APX

(c) 2018 The Authors. Published by Innovare Academic Sciences Pvt Ltd. This is an open access article under the CC BY license (http://creativecommons.org/licenses/by/4.0/) DOI: http://dx.doi.org/10.22159/ijcpr.2018v10i1.24702

\section{INTRODUCTION}

Wheat (Triticum aestivum) is the second-most produced crop on Earth and provides a large fraction of the dietary protein and total food supply. Wheat is one of the major cereals in the world and is one of the main sources of calories and protein. Approximately $85 \%$ and $82 \%$ of the global population depends on wheat for basic calories and protein, respectively [1]. It is grown all throughout the world in a wide variety of climates. It is a staple food for more than $35 \%$ of the world population. Moreover, this cereal is used in the production of a variety of wheat products, such as leavened bread, flat and steamed breads, cakes, pasta, biscuits, noodles, couscous and beer [2]. World trade in wheat is greater than for all other crops combined [3]. Globally, wheat is the leading source of vegetable protein in human food, having higher protein content than either maize (corn) or rice, the other major cereals. Ems is a common and effective chemical mutagen, especially recommended to create the mutations into the seed materials, whereas the observation and application of the mutation products are easy. Ems create point mutations in plants, on the other hand, deletion can also occur in lesser extent [4]. Thus, ems is powerful mutagen of changing loci of specific interest without inducing large deletions. Ems produces random mutations in the genetic material by nucleotide substitution;, particularly by guanine alkylation. This typically produces only point mutations. Mutation through ems in four varieties of wheat for herbicide resistance and other agronomic traits [5]. Few studies have examined ems doses in different crop species/cultivars. The efficiency of ems not only depends on ems quality but also on genotype [6].

The aim of this study is to determine the sensitivity of wheat cultivars HD 2894 (pusa wheat 109) (timely sown) with different doses of chemical mutagen ethyl-methane sulphonate (ems) by detecting the activity of enzymes and LPO behaviour of mutation in next-generation plants ( $\mathrm{m} 1, \mathrm{~m} 2$ and $\mathrm{m} 3$ ).

\section{MATERIALS AND METHODS}

\section{Chemicals}

The plant material Triticum aestivum (var. HD-2894) was taken from I. A. R. I., New Delhi used in the present study. Ems was purchased from Himedia Company. Tris hydrochloride, trichloroacetic acid (TCA) and 2-thiobarbutric acid (TBA) were purchased from SRL (Mumbai, India). All other chemicals used in current investigation were of analytical grade.

\section{Experimental design}

Presoaked seeds were treated with ems for $6 \mathrm{hr}$ with different doses of mutagen like $0 \%, 0.1 \%, 0.2 \%, 0.3 \%, 0.4 \%$ and $0.5 \%$. The seeds were kept in the mutagenic solution for $6 \mathrm{hr}$ at room temperature with shaking for providing uniform treatment to the dipped seed and equal no. of same genotypes were soaked in distilled water which served as control. After the treatment time is over, the seeds were washed in running tap water and then blotted dry. Out of 50, 20 seeds were sown in pot for all the concentrations and in control for a laboratory experiment. The effect of ems was observed by antioxidant activity and oxidative stress.

\section{Methods}

- Ascorbate Peroxidase (Apx) activity was examined by the method [7].

- Catalase activity was examined by the method [8].

- Glutathione reductase (GR) activity was examined by the method [9].

- Lipid Peroxidation (LPO) was examined by the method [10].

Statistical analysis: Data represent the mean \pm SD of three independent experiments. 


\section{RESULTS}

\section{Ascorbate peroxidase (APX) activity}

It was observed that total activity of apx was found to be reduced with increased concentration of mutagen, as compared to control.

\section{M1 generation}

After the $6 \mathrm{~h}$ time interval, the activity of apx was found to be reduced in variety HD-2894 with increased concentration of ems as compared to a control plant (fig. 1a).

\section{M2 generation}

In the $\mathrm{m} 2$ generation after given $6 \mathrm{~h}$ treatment of variety HD-2894 with different doses of ems the activity of apx increased till $0.2 \%$ $(0.1 \%-15.79 \mathrm{mg} / \mathrm{g}$ and $0.2 \%-15.56 \mathrm{mg} / \mathrm{g})$ compared to control and then decreased with increased concentration of mutagen (fig. 1b).

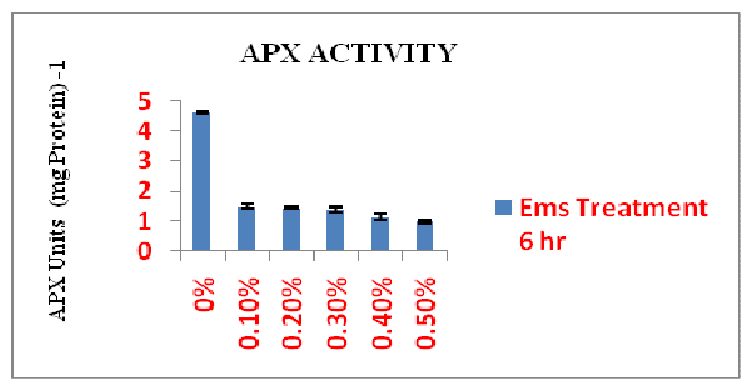

Fig. 1a: It shows the effect of ems with $6 \mathrm{~h}$ treatment on activity of ascorbate peroxidase (APX) in $\mathrm{m} 1$ generation wheat cultivar HD-2894: highest value obtained in 0\%-4.63 \pm 0.032 Data represent the means $\pm S D$ of three independent experiments

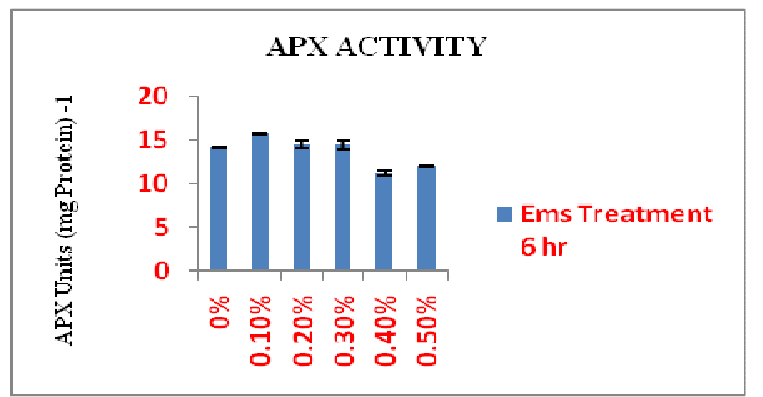

Fig. 1b: It shows the effect of ems with $6 \mathrm{~h}$ treatment on activity of ascorbate peroxidase (APX) in $\mathrm{m} 2$ generation in wheat cultivar HD-2894: highest value obtained in 0.1\%-15.79 \pm 0.07 and $0.2 \%-15.56 \pm 0.45$ Data represent the means \pm SD of three independent experiments

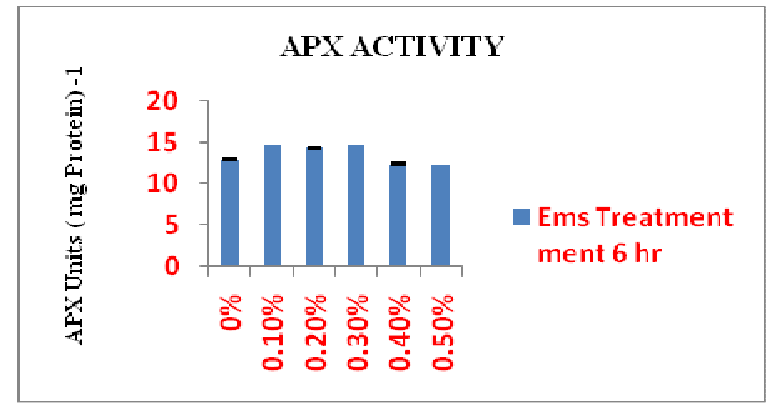

Fig. 1c: It shows the effect of ems with $6 \mathrm{~h}$ treatment on activity of ascorbate peroxidase (APX) in $\mathrm{m} 3$ generation in wheat cultivar HD-2894: highest value obtained in $0.1 \%$ $14.757 \pm 0.025,0.2 \%-14.36 \pm 0.104$ and $0.3 \%-14.763 \pm 0.037$. Data represent the means $\pm S D$ of three independent experiments

\section{M3 generation}

According to the analysis of $6 \mathrm{~h}$ treatment of variety HD-2894 with different doses of ems in an $\mathrm{m} 3$ generation, the activity of apx increased till $0.3 \%$ (0.1\%-14.757 mg/g, 0.2\%-14.36 mg/g and 0.3\%-14.763 mg/g) and then reduced with increased concentration of mutagen (fig. 1c).

\section{Catalase activity (CAT)}

\section{M1 generation}

In the first generation observation of variety HD-2894 with $6 \mathrm{~h}$ exposure of ems, catalase (CAT) activity was found to be decreased with increased concentration of ems as compared to control (fig. 2a).

\section{M2 generation}

According to the Second generation observation variety HD-2894 with $6 \mathrm{~h}$ exposure of ems mutagen, the further increment was observed till $0.3 \%(0.1 \%-0.0095 \mathrm{mg} / \mathrm{g}, 0.2 \%-0.0092 \mathrm{mg} / \mathrm{g}, 0.3 \%$ $0.0093 \mathrm{mg} / \mathrm{g}$ ) as compared to control and then decreased with increased conc. of mutagen (fig. 2b).

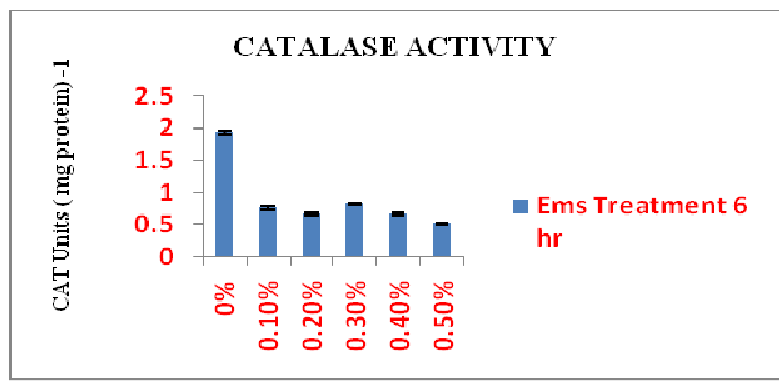

Fig. 2a: It shows the effect of ems with $6 \mathrm{~h}$ treatment on the activity of catalase (CAT) in $\mathrm{m} 1$ generation in wheat cultivar HD-2894: highest value was obtained in $0 \% 1.94 \pm 0.026$. Data represent the means $\pm S D$ of three independent experiments

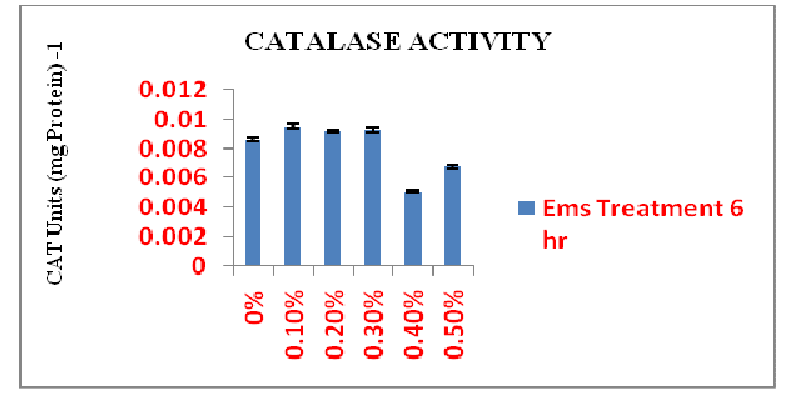

Fig. 2b: It shows the effect of ems with $6 \mathrm{~h}$ treatment on activity of catalase (CAT) in $\mathrm{m} 2$ generation in wheat cultivar HD-2894: highest value was obtained in $0.1 \%-0.0095 \pm 0.0017,0.2 \%$ $0.0092 \pm 0.0001$ and $0.3 \%-0.0093 \pm 0.00018$. Data represent the means \pm SD of three independent experiments

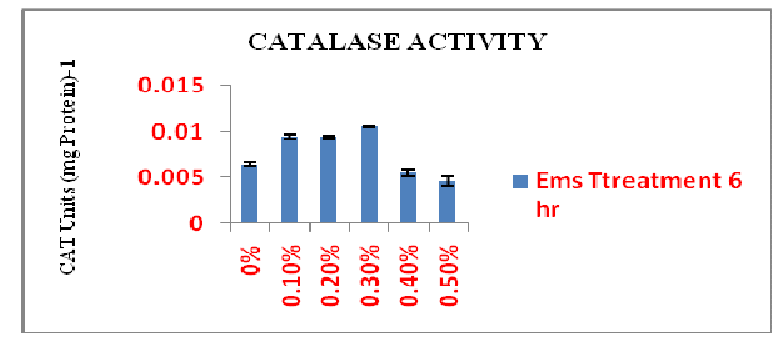

Fig. 2c: It shows the effect of ems with $6 \mathrm{~h}$ treatment on the activity of catalase (CAT) in $\mathrm{m} 3$ generation in wheat cultivar HD-2894: highest value was obtained in 0.1\%-0.0094 \pm 0.00028 , $0.2 \%-0.0094 \pm 0.001$ and $0.3 \%-0.0105 \pm 0.00011$. Data represent the means $\pm S D$ of three independent experiments 


\section{M3 generation}

In the wheat cultivar of HD-2894 with $6 \mathrm{~h}$ exposure of mutagen, catalase (CAT) activity was found to be increased till $0.3 \%(0.1 \%$ $0.0094 \mathrm{mg} / \mathrm{g}, 0.2 \%-0.0094 \mathrm{mg} / \mathrm{g}$ and $0.3 \%-0.0105 \mathrm{mg} / \mathrm{g}$ ) compare to control and then found to be decreased with increased concentration of mutagen (fig. 2c).

\section{Glutathione reductase enzyme activity}

\section{M1 generation}

In the first generation observation of variety HD-2894 with $6 \mathrm{~h}$ exposure of ems mutagen, glutathione reductase (GR) activity was found to be reduced with increased concentration of mutagen as compared to control (fig. 3a).

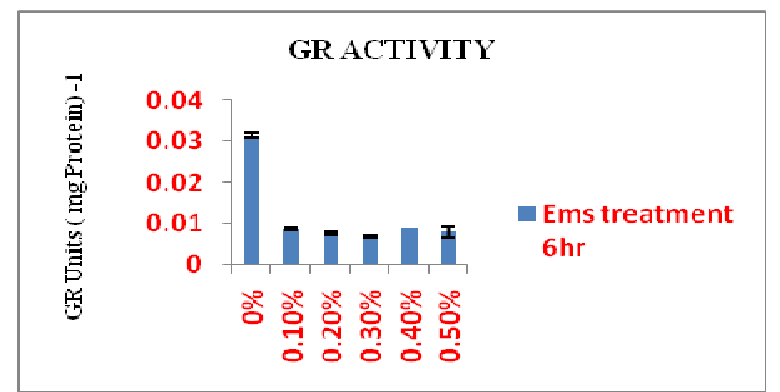

Fig. 3a: It shows the effect of ems with $6 \mathrm{~h}$ treatment on glutathione reductase (GR) content of $m 1$ generation in wheat cultivar HD2894: highest value was recorded in $0 \%-0.0315 \pm 0.000577$. Data represent the means \pm SD of three independent experiments

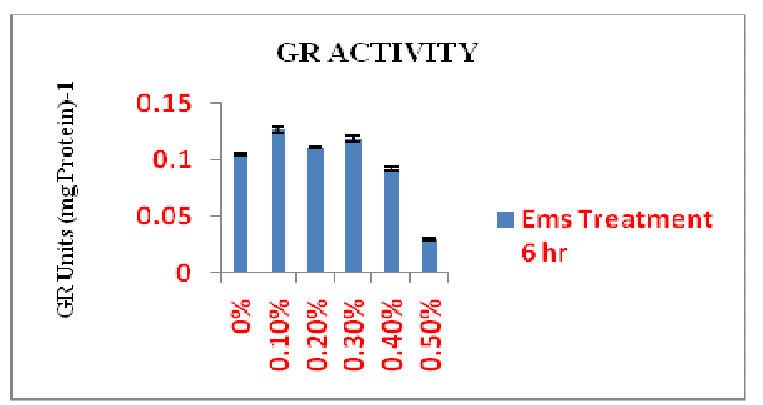

Fig. 3b: It shows the effect of ems with $6 \mathrm{~h}$ treatment on glutathione reductase (GR) content of $\mathrm{m} 2$ generation in wheat cultivar HD2894: highest value was recorded in $0.1 \%-0.127 \pm 0.00289$ and $0.2 \%-0.111 \pm 0.00577$ and $0.3 \%-0.119 \pm 0.0208$. Data represent the means $\pm S D$ of three independent experiments

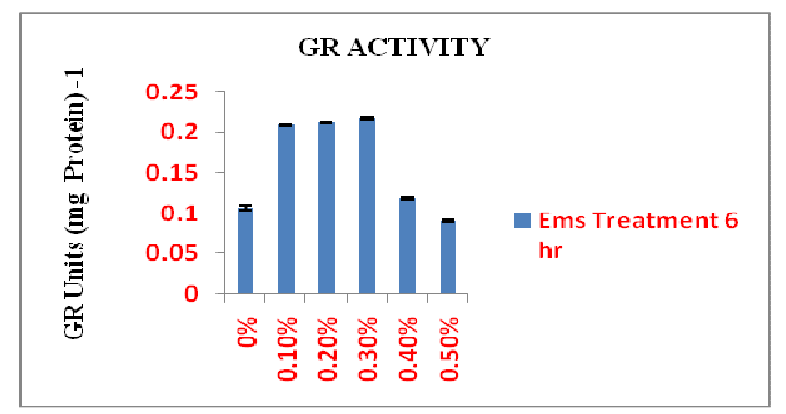

Fig. 3c: It shows the effect of ems with $6 \mathrm{~h}$ treatment on glutathione reductase (GR) content of $m 3$ generation in wheat cultivar HD2894: highest value was recorded in the concentration of $0.1 \%$ $0.209 \pm 0.003,0.2 \%-0.212 \pm 0.001,0.3 \%-0.219 \pm 0.0015$ and $0.4 \%$ $0.118 \pm 0.0011$, data represent the means $\pm S D$ of three independent experiments

\section{M2 generation}

According to the Second generation observation of variety HD2894 with $6 \mathrm{~h}$ exposure of ems mutagen, activity of glutathione reductase (GR) was found to be increased till $0.3 \%$ (from $0.1 \%$ $0.127 \mathrm{mg} / \mathrm{g}, 0.2 \%-0.111 \mathrm{mg} / \mathrm{g}$ and $0.3 \%-0.119 \mathrm{mg} / \mathrm{g}$ ) as compared to control and then decreased with the increased concentration of mutagen (fig. 3b).

\section{M3 generation}

In the cultivar of HD-2894 with $6 \mathrm{~h}$ exposure of mutagen, glutathione reductase (GR) activity was found to be increased till $0.4 \%(0.1 \%-0.209 \mathrm{mg} / \mathrm{g}, 0.2 \%-0.212 \mathrm{mg} / \mathrm{g}, 0.3 \%-0.219 \mathrm{mg} / \mathrm{g}$ and $0.4 \%-0.118 \mathrm{mg} / \mathrm{g}$ ) as compared to control and then found to be reduced with the increased concentration of mutagen (fig. 3c).

\section{Lipid peroxidation (LPO) activity}

\section{M1 generation}

In the first generation observation of variety HD-2894 with $6 \mathrm{~h}$ exposure of ems mutagen at 530 and $600 \mathrm{~nm}$, it was observed that the activity was found to be increased in $530 \mathrm{~nm}$ till $0.1 \%(0.1 \%$ $0.038 \mathrm{mg} / \mathrm{g}$ ) as compared to control and the again found to be higher in $0.3 \%(0.3 \%-0.00833 \mathrm{mg} / \mathrm{g})$ at $600 \mathrm{~nm}$ and then again reduced with the increased concentration of mutagen (fig. 4a).

\section{M2 generation}

According to the Second generation observation of variety HD-2894 with $6 \mathrm{~h}$ exposure of ems at $530 \mathrm{~nm}$, the increment was observed till $0.3 \%$ (from $0.1 \%-0.045 \mathrm{mg} / \mathrm{g}, 0.2 \%-0.053 \mathrm{mg} / \mathrm{g}, 0.3 \%-0.056 \mathrm{mg} / \mathrm{g}$ ) as compared to control and then decreased with the increased concentration of mutagen. According to the observation of variety HD-2894 with $6 \mathrm{~h}$ exposure of ems at $600 \mathrm{~nm}$, the increment was observed in $0.2 \%$ and $0.3 \%$ (from $0.2 \%-0.052 \mathrm{mg} / \mathrm{g}, 0.3 \%-0.057$ $\mathrm{mg} / \mathrm{g}$ ) as compared to control and then decreased with the increased concentration of mutagen (fig. $4 \mathrm{~b}$ ).

\section{M3 generation}

According to the third generation observation of variety HD-2894 with $6 \mathrm{~h}$ exposure of ems at $530 \mathrm{~nm}$, the increment was observed till $0.3 \%$ (from $0.1 \%-0.107 \mathrm{mg} / \mathrm{g}, 0.2 \%-0.108 \mathrm{mg} / \mathrm{g}$ and $0.3 \%-0.110$ ) as compared to control and then decreased with the increased concentration of mutagen. According to the analysis of HD-2894 with $6 \mathrm{~h}$ exposure of ems at $600 \mathrm{~nm}$, the increment was observed till $0.3 \%$ (from $0.1 \%-0.106 \mathrm{mg} / \mathrm{g}, 0.2 \%-0.108 \mathrm{mg} / \mathrm{g}$ and $0.3 \%-0.112$ $\mathrm{mg} / \mathrm{g}$ ) as compared to control and then reduced with the higher concentration of mutagen (fig. 4c).

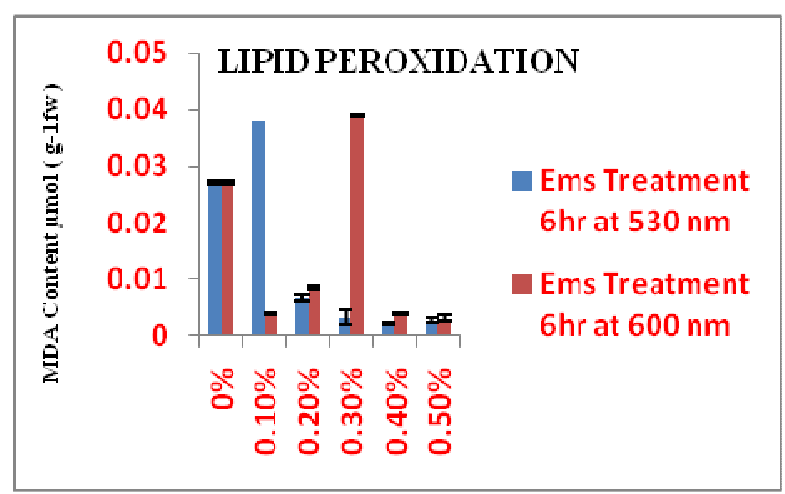

Fig. 4a: It shows the effect of ems with $6 \mathrm{~h}$ treatment on lipid peroxidation (LPO) content of $\mathrm{m} 1$ generation in wheat cultivar HD-2894: Highest value was recorded in the concentration of $0.1 \%-0.038 \pm 0.001$ at $530 \mathrm{~nm}, 0.3 \%-0.00833 \pm 0.002$ at $600 \mathrm{~nm}$ data represent the means \pm SD of three independent experiments 


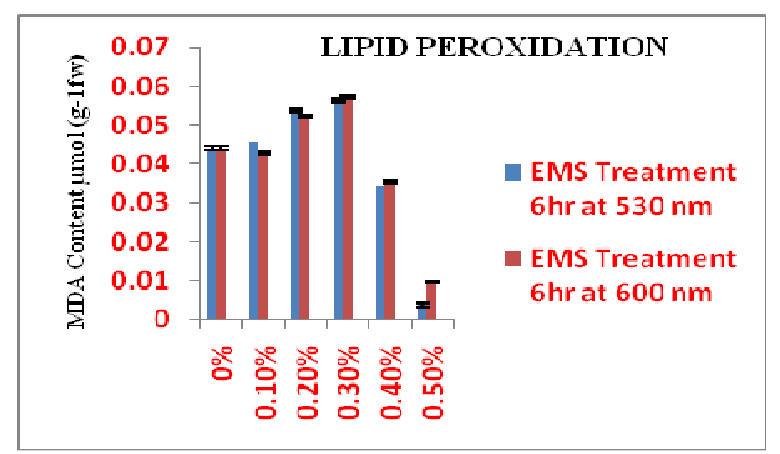

Fig. 4b: It shows the effect of ems with $6 \mathrm{~h}$ treatment on lipid peroxidation (LPO) content of $\mathrm{m} 2$ generation in wheat cultivar HD2894: Highest value was recorded in the concentration of $0.1 \%$ $0.0457 \pm 0.001,0.2-0.0539 \pm 0.00037$ and $0.3-0.0563 \pm 0.00252$ at 530 $\mathrm{nm}, 0.2 \%-0.052 \pm 0.0025$ and $0.3 \%-0.057 \pm 0.0029$ at $600 \mathrm{~nm}$. Data represent the means $\pm S D$ of three independent experiments

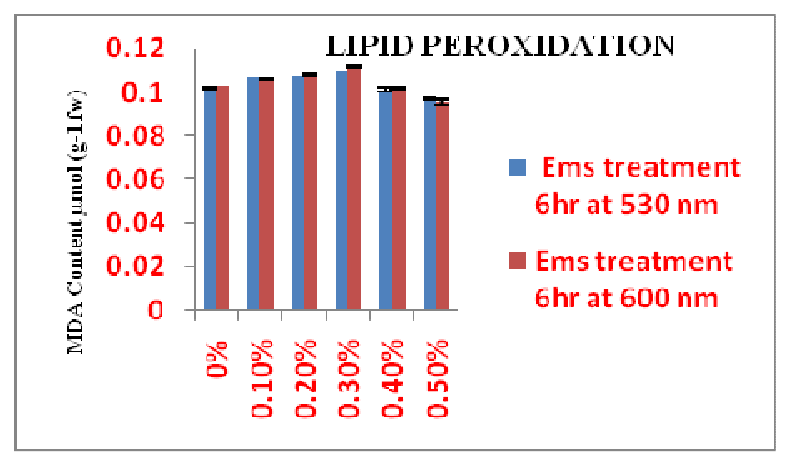

Fig. 4c: It shows the effect of ems with $6 \mathrm{~h}$ treatment on lipid peroxidation (LPO) content of $\mathrm{m} 3$ generation in wheat cultivar HD-2894: Highest value was recorded in the concentration of $0.1 \%-0.107 \pm 0.0001,0.2-0.108 \pm 0.0001$ and $0.3-0.110 \pm 0.0001$ at $530 \mathrm{~nm}, 0.1-0.106 \pm 0.001530 .2 \%-0.108 \pm 0.00153$ and $0.3 \%$ $0.112 \pm 0.00257$ at $600 \mathrm{~nm}$. Data represent the means $\pm S D$ of three independent experiments

\section{DISCUSSION}

We observed in the laboratory condition, ems mutagenesis caused significant reduction and stability in the activity of antioxidants and lipid peroxidation in $\mathrm{m} 1, \mathrm{~m} 2$ and $\mathrm{m} 3$ generation. This was manifested as a significant delay in the activity of antioxidants as the ems concentration was increased. Among the chemical mutagens and alkalizing agents, ems has especially been demonstrated to be the most potent. Previous studies affirm that while the mutagenesis response is more or less linear with the dose, polyploids are more tolerant than diploids [11].

Apx is one of the important enzymes which utilizes ascorbate as an electron donor and used as key component of ascorbate-glutathione (AsA-GSH cycle) pathway and regulates the level of $\mathrm{H}_{2} \mathrm{O}_{2}$ in the plant. According to Fig. $1 \mathrm{a}$ in the $\mathrm{m} 1$ generation the results showed that $6 \mathrm{~h}$ treatments of ems were applied, the activity of apx decreased significantly with the increasing concentration of ems. Our results showed that after treatment of wheat cultivar with different doses of ems in $\mathrm{m} 2$ generation the activity of apx increased till $0.2 \%$ then decreased with increasing concentration of ems. To identify the activity of apx in $\mathrm{m} 3$ generation, $6 \mathrm{~h}$ treatments with different doses of ems, the activity of apx increased till $0.3 \%$ then decreased with increased concentration of ems. Researchers reported that increased apx activity has been reported in osmotically-stressed wheat leaves [12].

Catalase is exceptionally one of the universal enzymes that remove $\mathrm{H}_{2} \mathrm{O}_{2}$ by breaking down directly into water and oxygen without any requirement of reducing power [13]. In the $m 1$ generation, there is no increment in the activity of CAT enzyme due to the exposure of ems, but in $\mathrm{m} 2$ and $\mathrm{m} 3$ generation our findings showed that activity of CAT enhances till $0.2 \%$ and $0.3 \%$ respectively against the exposure of ems. The increment in activities of cat observed in this study, emphasize the roles these enzymes perform to protect plant cells from the destructive effects of reactive oxygen species (ROS) as key components of the cellular antioxidant defence system.

Glutathione reductase is also one of the key enzymes, which plays a central role in maintaining the redox environment of plants by converting oxidized glutathione to reduced glutathione using NADPH as a reducing agent. Higher GR activity was also reported in crop plants like wheat, sorghum, pigeon pea and foxtail millet [1416, 17]. The efficiency of antioxidant enzymes determines the amount of dehydration-induced $\mathrm{H}_{2} \mathrm{O}_{2}$ in plant cell [18]. Ros are responsible for stress-induced peroxidation of membrane lipids due to more production of mda and often used as an indicator of increased oxidative damage. Plants develop several antioxidants that aid in antioxidant defence system, protecting plants against damage caused by active 02 formed due to exposure to UV radiation [19]. Antioxidants from plants prevent the action of free radicals, so there is growing interest all over the world to identify the untapped reservoir of plants of medicinal importance [20].

\section{CONCLUSION}

The effects of ems appear soon after sowing the seeds and can be observed by naked eyes. Therefore, ems should be used to create a mutation in many crops like wheat, which are highly susceptible for harmful pathogens and made them economically inexpensive and beneficial for farmers.

\section{ACKNOWLEDGEMENT}

The authors sincerely express their gratitude to Banasthali University and Department of Science and Technology (DST), India for giving the facilities for completion of the research work and also thanks to Dept. of Bioscience and Biotechnology Banasthali University for their valuable support and encouragement throughout the entire period of research.

\section{AUTHORS CONTRIBUTIONS}

Shailja Dubey conducted experiments and prepared manuscript, Dr. Renu Bist helped in the manuscript preparation and Dr. Shrilekha Misra conceived and oversaw the project, as well as designing of experiments and manuscript preparation.

\section{CONFLICT OF INTERESTS}

There is no conflict among the authors

\section{REFERENCES}

1. Chaves MS, Martinelli JA, Wesp GC, Graichen FAS, Brammer S, Scagliusi SM, et al. The importance for food security of maintaining rust resistance in wheat. Food Secur 2013;5:157-76.

2. Curtis T, Halford NG. Food security: the challenge of increasing wheat yield and the importance of not compromising food safety. Ann Appl Biol 2014;164:354-72.

3. Curtis BC, Rajaram S, Gomez Macpherson H. Bread wheat: improvement and production. FAO Rome; 2002.

4. Okagaki RJ, Neuffer MG, Wessler SR. A deletion common to two independently derived waxy mutations of maize. Genetics; 1991. p. 425-31.

5. Ndou VN, Shimelis H, Odindo A, Modi AT. The response of selected wheat genotypes to ethyl methane sulphonate concentration, treatment temperature and duration. Sci Res Ess 2013;8:189-6.

6. Kodym A, Afza R. Physical and chemical mutagenesis methods. Mol Biol 2003;236:189-204.

7. Chen GX, Asada K. Ascorbate peroxidase in tea leaves: occurrence of two isoenzymes and the differences in their enzymatic and molecular properties. Plant Cell Physiol 1989;30:987-98.

8. Aebi H. Catalase in vitro. In: Packer L. editor. Methods in enzymology. Orlando: Academic 1984;105:121-6. 
9. Schaedle M, Bassham JA. Chloroplast glutathione reductase. Plant Physiol 1977;59:1011-2.

10. Heath RL, Packer L. Photoperoxidation in isolated chloroplasts: Kinetics and stoichiometry of fatty acid peroxidation. Arch Biochem Biophys 1968;125:189-8.

11. Chopra VL. Mutagenesis: investigating the process and processing the outcome for crop improvement. Curr Sci 2005; 8:353-9.

12. Lascano HR, Antonicelli GE, Luna CM, Melchiorre MN, Gomez LD, Racca RW, et al. Antioxidant system response of different wheat cultivars under drought field and in vitro studies. Aust J Plant Physiol 2001;28:1095-102.

13. Lata C, Jha S, Dixit V, Sreenivasulu N, Prasad M. Differential antioxidative responses to dehydration-induced oxidative stress in a core set of foxtail millet cultivars (Setaria italica L.). Protoplasma 2011;248:817-28.

14. Jogeshwar G, Pallela R, Jakka NM, Reddy PS, Rao JV, Sreenivasulu $\mathrm{N}$, et al. Antioxidative response in different sorghum species under short-term salinity stress. Acta Physiol Plant 2006;28: 465-75.
15. Kumutha D, Ezhilmathi K, Sairam RK, Srivastava GC, Deshmukh PS, Meena RC. Waterlogging induced oxidative stress and antioxidant activity in pigeon pea genotypes. Biol Plant 2009;53:75-84.

16. Selote DS, Khanna-Chopra R. Antioxidant response of wheat genotypes tolerance. Protoplasma 2010;245:153-63.

17. Lata C, Jha S, Dixit V, Sreenivasulu N, Prasad M. Differential antioxidative responses to dehydration-induced oxidative stress in a core set of foxtail millet cultivars (Setaria italica L.). Protoplasma 2011;248:817-28.

18. Luna CM, Pastori GM, Driscoll S, Groten K, Stephanie B. Drought controls on $\mathrm{H}_{2} \mathrm{O}_{2}$ accumulation, cat activity and cat gene expression in wheat. J Exp Bot 2005;56:417-23.

19. Rose IA, Uma RV. A comparative study on in vitro antioxidant and antibacterial activities of methanol extract from the leaves of Stachytarpheta indica (L) vahl and Premna corymbosa rotil. Int J Curr Pharm Res 2015;7:43-8.

20. Dua D, Srivastava NS. A study on antioxidant and anti-aging properties of few medicinal plants. Int J Pharm Pharm Sci 2016;8:344-7. 